\title{
PROFITABILITY OF VALUE ADDITION TO CASHEW FARMING HOUSEHOLDS INNIGERIA
}

\author{
J.O. LAWAL, O.O. ODUWOLE, T.R. SHITTU and A.A. MUYIWA \\ Cocoa Research Institute of Nigeria (CRIN), P.M.B. 5244, Ibadan, Nigeria \\ Corresponding author: yemisilawal2003@yahoo.com
}

(Received 4 October, 2009; accepted 10 December, 2010)

\begin{abstract}
The cashew tree (Anacardium occidentale L.) is an economic crop in Nigeria grown in small plantations in almost every State because of the ease of cultivation and need for minimum attention. Cashew apple wastes on plantations and this reduces cashew farming household incomes. This study examined value addition to cashew as a way of preventing farm losses due to wastage and lack of proper storage of the cashew apple Nigeria. The process of value addition involved the kernels being graded, heat treated, shelled roasted and packaged. The apples were crushed, processed to juice and bottled for sale. There was a significant difference $(\mathrm{P}<0.05)$ between net income per farmer adding value (US\$487.26) and not adding value (US\$306.29). Also, the benefit-cost ratio of adding value was $1: 2.30$.
\end{abstract}

Key Words: Benefit-cost ratio, budgetary analysis

\section{RÉSUMÉ}

Le noix de cajou (Anacardium occidentale L.) est une culture économique au Nigeria. Elle est cultivée dans de petites plantations dans presque chaque Etat par ce qu'elle est facile à cultiver et requiert une attention minimale. Les pommes de cajou sont souvent abandonées dans des plantations, ce qui réduit son revenu au niveau des ménages. Cette étude examine la valeur ajoutée du cajou comme un moyen de prévention des pertes dans les fermes dues au gaspillage et au manque de moyen approprié de stockage des pommes de cajou au Nigeria. Le processus de l'addition de la valeur concernait le gradage, traitement à chaud, décoqillage, grillage et emballage des grains de cajou. Les pommes étaient presses, transformées en jus embouteillé pour vente. Il était observé une différence significative $(\mathrm{P}<0.05)$ entre le revenue net sur la valeur ajoutée par fermier (US\$487.26) et celui des produits non transformés (US\$306.29). Aussi, le rapport bénéfice-coût de l’ajout de la valeur au produit était de $1 ; 2.30$

Mots Clés: Rapport bénéfice-coût, analyse budgétaire

\section{INTRODUCTION}

The cashew tree (Anacardium occidentale Linn.) is widely cultivated across the coastal regions of the tropics (Gibbon and Pain, 1985; Naggy et al., 1990). Overall cashew production in Africa steadily increased during the 1950s - mid-1970s when the continent was the prime producer of cashew nuts. The year 1975 was the start of a fifteen year period of decline in production throughout the continent due to a combination of biological, agronomic and socio-political factors. The decline in prices at the end of the 1970s, combined with lower levels of production, dissuaded many farmers from improving cultivation techniques and replanting their cashew plantations (Andrighetti et al., 1998). 
Since the early 1990s, production has recovered and has continued to increase steadily. Today, Africa accounts for about 36 percent of world cashew production. Historically, Mozambique and Tanzania were the main cashewproducing countries in Africa, with smaller amounts produced in a number of other countries (ARWP, 2004). During the past decade, the production of cashew nuts in Nigeria has increased almost six-folds from 30,000 tonnes in 1990 to 176,000 tonnes in 2000. Prior to this, production was relatively static at 25,000 tonnes over a 25 years from 1965 (Olunloyo, 1996). As in the case of other developing countries, Nigeria has recognised the potential economic value of cashew and has made a concerted effort to improve production of the crop. During the last five to ten years, Nigeria has emerged as a leading producer of cashew nuts in Africa (Ogunsina and Lucas, 2008).

Presently in Nigeria, products of the cashew tree (kernel and apple) are under-utilised for income generation. There is still much wastage of the fresh apples on farms since a negligible portion is consumed by the harvesters. This wastage reduces the household income. It is, thus, imperative that value addition to cashew apple and nut be explored.

Value addition has been found to improve income and shelf-life of product on crops like cocoa (Lawal and Jaiyeola, 2007). This study determined the returns in form of income to households practicing cashew value addition by converting the apples to juice and kernels to roasted nut for commercial sales.

\section{METHODOLOGY}

The study was carried out in Kogi State, Latitude: +7.4 (7²4’00"N), Longitude: +7.63 (7³7’48"E) which, is prominent for cashew production in Nigeria. Two high cashew producing Local Government Areas, Kabba-Bunu and Dekina, were purposively selected for the study. From each LGA, two communities were randomly chosen from a list of cashew producing LGAs provided by the State Agricultural Development Programme.
From the four communities, one hundred and fifty respondents were randomly selected proportionate to the number of cashew farmers in each of the communities. The sample was then split into those adding value and not adding value. The process of value addition involves processing raw cashew kernel into nuts. It is generally time consuming and labour intensive, involving grading, heat treatment of kernels, shelling, peeling and packaging.

Cashew apple juice/ syrup is made from ripe cashew apples after washing using screw press to extract juice and bottled for sale. Information was collected from the respondents using a structured questionnaire and multistage sampling technique.

Descriptive statistics were used to analyse the socio- economic characteristics of the cashew farming households in the study areas. Budgetary analysis was used to estimate the gross margin following Adegeye and Dittoh (1985).

T-test was used to evaluate the significant differences between means of the gross margin of those adding value and those not (Snedecor and Cochran, 1989).

A multiple Regression model was used to estimate the relationship between household income and socio-economic variables (en.wikipedia.org/wiki/Regressionanalysis) and is stated as follows:

$\mathrm{Y}=\mathrm{f}\left(\mathrm{X}_{1}, \mathrm{X}_{2}, \mathrm{X}_{3}, \mathrm{X}_{4} \mathrm{X}_{5} \mathrm{X}_{6}, \mathrm{X}_{7}, \mathrm{e}_{1}\right)$

Where:

Y= Household income (Nigerian Naira, $\mathrm{N}$ )

$\mathrm{X}_{1}=$ age (years)

$\mathrm{X}_{2}=\operatorname{sex}($ male $=1$, female $=0)$

$\mathrm{X}_{3}=$ farming experience (years)

$\mathrm{X}_{4}=$ farm size (ha)

$\mathrm{X}_{5}=$ household size (number in household)

$\mathrm{X}_{6}=$ value addition (farmer adding value $=1$, otherwise $=0$ ) 
$\mathrm{X}_{7}=$ access to credit (having access $=1$, otherwise $=0$ )

$\mathrm{e}=$ error term

\section{RESULTS AND DISCUSSION}

Table 1 shows the socio-economic characteristics of the respondents. The average age of cashew farmer in Kogi State was 56 years, which indicates that most cashew farmers are elderly with large household sizes of 7 members. The years of cashew farming span over 27 with the average age of cashew plantations at 26 years. The average cashew farm size was 2.5 hectares.

The above result shows that with the limited mean farm size available to the aging farmers, there is need to diversify the use to which their produce from the farms is put to by adding value. This will ensure that they maximise their profits from the small farm for their household food security, most especially, as the cashew farms are getting old too. And with the advantage of large household size, this can be easily achieved if they see the prospect and gains that can accrue to them from value addition. Lawal et al., 2009 also found similar characteristics existing among cocoa farming households in Nigeria.
Table 2 shows results of the costs and the returns from cashew production by costing both fixed and variable input of production by the farmers. It is clear that the gross margin as well as the average net income per farmer were US\$495.55 and 487.26, respectively. The profit per farmer adding value to apples and nuts stood at US\$ 566.42 per tonne of cashew.

It is apparent that the gross revenue, gross margins and net income per farmers adding value are higher at (\$566.42; \$495.55 and \$487.26) than those of farmers not adding value (\$378.28; $\$ 313.83$ and \$306.49). The profit accruable to a farmer not adding value was US\$378.28. There is a profit margin of US\$188 between the two groups. Also, the t-cal (5.18) is higher than the t-tabulated (2.63). This implies there was a significant difference $(\mathrm{p}<0.05)$ in that net income of farmers adding value to cashew and those not (Table 3 ). The increase in all these indicators among the farming households adding value is due to the extra efforts on the nuts and apples. The profitability analysis using the benefit-cost ratio shows 1:2.30 which implies that for every Naira spent on value addition process, the household gets back $2.30 \mathrm{k}$ (Two Naira, thirty kobo) which is two and half of whatever is expended as returns. When this is ploughed into their farming and

TABLE 1. Statistics of socioeconomic characteristics of cashew farmers

\begin{tabular}{lrrr}
\hline Characteristics of cashew farmers & \multicolumn{3}{c}{ Study area Site (means) } \\
\cline { 2 - 4 } & Kabba & Dekina & Kogi state \\
\hline \multirow{2}{*}{ Age (years) } & 56.12 & 56.53 & 56.33 \\
& -9.47 & -10.08 & -9.75 \\
Household size & & & \\
& -3.13 & 6.8 & 7.47 \\
Years of cashew farming & & -3.04 & -3.72 \\
& 29.38 & 26.43 & 27.91 \\
Age of cashew farm (years) & -9.97 & -12.26 & -11.24 \\
Farm size (ha) & & & \\
& 24.75 & 27.44 & 26.09 \\
& -11.13 & -12.58 & -11.91 \\
& 2.35 & 2.5 & 2.47 \\
\hline
\end{tabular}

Figures in parenthesis are standard deviation; Source: Field survey, 2009 
TABLE 2. Cost and returns to farmers' adding value to their cashew

\begin{tabular}{lrr}
\hline Item (tonnes) & $\begin{array}{r}\text { Value added } \\
\text { Amount (A) }\end{array}$ & $\begin{array}{c}\text { Value not added } \\
\text { Amount (A) }\end{array}$ \\
\hline Total variable cost & $1,594,520$ & $1,449,913$ \\
Average variable cost & 10,630 & 9,666 \\
Total fixed cost & 186,645 & 169,780 \\
Average fixed cost/farmer & 1,244 & 1,131 \\
Total cost & $1,781,165$ & $1,619,693$ \\
Average total costffarmer & 11,874 & 10,798 \\
Gross revenue & $12,744,408$ & $8,511,240$ \\
Gross revenue/farmer & 84,963 & 56,742 \\
Gross margin & $11,149,960$ & $7,061,327$ \\
Gross margin/farmer & 74,333 & 47,075 \\
Net income & $10,963,315$ & $6,891,547$ \\
Net income/farmer & 73,08 & 45,944 \\
Benefit cost ratio & $2.30: 1$ & \\
\hline
\end{tabular}

Source: Field survey, 2009; US\$1= A 150

TABLE 3. Results of T-test on net income per farmer adding value and those not

\begin{tabular}{lrr}
\hline Statistics & Adding value & Not adding value \\
\hline Mean net Income & 73,089 & 45,974 \\
Standard deviation & $37,222.62$ & $20,865.98$ \\
Standard error of mean & $4,581.78$ & $3,578.49$ \\
Number & 66 & 84 \\
& & \\
T-cal $=5.18$ & \\
T-tab $=2.63$ & \\
\hline
\end{tabular}

Source: computer printout, 2009; * Significant at 5\% level processing businesses all over, it can improve their efficiency, productivity, income and general welfare of the farming households thus making them to escape from poverty.

There were significant differences $(\mathrm{p}<0.05)$ in the gross margin of the farmers adding value and those not adding value (Table 3 ). The significance might be due to the fact that the farmers adding value derived special benefits in terms of cash income from the value added products, thus, making their gross margin be substantially different from those farmers not adding value. This result is in consonance with the findings of

TABLE 4. Regression results of estimates of relationship of household Income and farmers' characteristics

\begin{tabular}{lccc}
\hline Variables & Coefficients & Standard error & t-values \\
\hline$X_{1}$-Age & -0.684 & 0.249 & -2.746 \\
$X_{2}$-Gender & -0.367 & 0.400 & -0.917 \\
$X_{3}$ - Farm experience & 0.486 & 0.129 & $3.767^{\star}$ \\
$X_{4}$ - Household size & 684 & 0.249 & $2.746^{*}$ \\
$X_{5}$-Farm size & 6.864 & 2.086 & $3.291^{*}$ \\
$X_{6}$-Value addition & 4.635 & 1.386 & $3.344^{*}$ \\
$X_{7}$-Access to credit & 4.383 & 1.389 & $3.156^{\star}$ \\
$R^{2}$ & & & \\
F-Value & & & \\
\hline
\end{tabular}

Source: Field survey data, 2009; *Significant at $5 \%$ level 
Amusan et al. (2005) and Lawal and Jaiyeola (2007) on cocoa.

Regression results show that variables with the positive signs are significant (5\% level of probability) except age and gender (Table 4). A year's increase in farming experience of the farmer $\mathrm{X}_{3}$, will increase the probability of household income by 0.49 . This is because experience might have taught the farmers to know the best and right time to harvest for value addition and, hence, get more money in return (Enete et al., 2002) reported that years of experience had a positive impact on production systems and household income among women farmers in Nigeria.

An increase by one person in household size $\mathrm{X}_{4}$, increased the probability of household income by 0.68 . This may be the result of having more hands to work on the process of value addition, thereby reducing the cost of labour and, hence, improving their profit margins. Also, a hectare increase in the farm size $X_{5}$, increases the probability of household income by 6.86 . This is because, ceteris paribus, the bigger the farm, the more produce harvested from the farm. On the other hand, value addition $\mathrm{X}_{6}$, and access to credit $\mathrm{X}_{7}$ resulted in increased income for the cashew farming household by 4.64 and 4.38 , respectively. These indicate positive and significant relationships exist between household income and value addition on Cashew.

\section{CONCLUSION}

Value addition to cashew nuts and apples (fruits) increases income for the farming households in Nigeria. Value addition, in particular doubles income/ revenue accruable to cashew farming households based on the benefit-cost ratio. Value addition to cashew is positively related to increase in household income.

\section{ACKNOWLEDGEMENT}

The kind cooperation of the Agricultural Development Programme Officers and Cashew Farmers in Kabba and Ochaja Areas of Kogi State, Nigeria is acknowledged for the successful completion of the field work on this study. Thanks also to African Women in Agricultural Research and Development (AWARD) of which Justina Lawal is a fellow, for the opportunity of reviewing and sharpening the contents of this paper at the scientific writing workshop she attended in Maputo, Mozambique in January, 2010.

\section{REFERENCES}

Adegeye, A.J. and Dittoh, J.S. 1985. Essential of Agricultural Economics. Ibadan. Impact Publishers Nig. Ltd. pp. 63-67.

Amusan, O.A., Amusan, F.O., Braimoh, A and Oguntade, P. 2005. Quality management practices in cocoa production in South Western Nigeria. In: Proceedings of Tropentag 2005 International Research Conference on Food Security, Natural Resource Management and Rural Development. University of Hohenheim, Stuttgart. October 11-13, 2005 Pg 51-56.http:/ /www.tropentag.de/2005/abstracts/full/ 29.pdf.

Andrighetti, L., Bassi, G.F., Capella, P., De Logu, A.M.,Deolalikar, A.B., Haeusler, G., Franca, F.M.C., Rivoira, G., Vannini, L. and Deserti R.N. 1994. The world cashew economy. L'inchiostroblu: Nomisma Economic Research Centre, Italy.

African Region Working Paper Series 70. Viewed at: http://www.worldbank.org/afr/wps/ index.htm January 24th, 2010.

Enete, A.A., Nweke, F.I. and Tollens, E. 2002. Determinants of cassava cash income in female headed households of Africa. Quarterly Journal of International Agriculture 41.

Gibbon, D. and Pain, A. 1985. Crops of the Drier Regions of the Tropics. Longman Press, London, UK. pp. 23-25.

Lawal, J.O. and Jaiyeola, C.O. 2007. Economic analysis of cocoa wine produced from cocoa powder. www.world-food.net. Journal of Agric, Food and Environment 5(2):76-77.

Lawal, J.O., Omonona, B.T., Ajani, O.I.Y. and Oni, A.O. 2009. Determinants of constraint to credit access among cocoa farming households in Osun State, Nigeria. Pakistan Journal of Social Sciences 6(3):159-163. 
Naggy, S., Shaw, P.E. and Wardowski, W.F. 1990. Olunloyo, O.A. 1996. Cashew and its Fruits of tropical and sub-tropical origin. Composition, properties and uses. Florida Sci. Source Press Inc., Florida, U.S.A.

Ogunsina,B.S. and Lucas, E.B. 2008. Development of a manually operated cashew juice extractor. Agricultural Engineering International: The CIGR E Journal 3(2). potentialities. Proceedings of the National Workshop 'Cashew Production Technology', March 26-29, Cocoa Research Institute of Nigeria (CRIN), Ibadan, Nigeria.

Snedecor, G., Cochran, W. and Cox, D. 1989. Statistical Methods ( $8^{\text {th }}$ edition). The Iowa State University Press. 